\title{
Academic Research Strengths and Multinational Firms' Foreign R\&D Location Decisions: Evidence from Foreign R\&D Projects in European Regions
}

\author{
Rene Belderbos \\ KU Leuven, UNU-MERIT and Maastricht University \\ Vincent Van Roy \\ KU Leuven \\ Bart Leten \\ KU Leuven, Vlerick Leuven Gent Management School \\ Bart Thijs \\ KU Leuven, ECOOM
}

\begin{abstract}
Although an expanding literature on university-industry linkages has suggested that proximity to academia can increase the innovative performance of firms, the role of academic research in the R\&D location choices by multinational firms has received surprisingly little attention. In this paper we analyze to what extent academic research in host regions of EU-15 countries attracts R\&D investments by multinational firms. We analyze the determinants of the location of 394 multinational R\&D projects in NUTS-1 regions of EU-15 countries during the period 2003-2008. We construct precise measures of the academic research strengths of regions by using annual WoS publication data. We count university publications at the level of regions and science fields, and measure relevant publications for investing firms by linking science fields to the industry that firms are active in. We find that the probability to locate $\mathrm{R} \& \mathrm{D}$ projects in a host region is positively affected by the host region's academic strength - after controlling for industry agglomeration, the technological strength of the region, $R \& D$ tax incentives, and other characteristics of host locations. Our results further suggest that in addition to providing knowledge spillovers, a major mechanism through which academic research attracts foreign R\&D is the supply of graduates with a PhD.
\end{abstract}

Acknowledgements. This research was partially funded by the Flemish policy research center on entrepreneurship and international entrepreneurship (STOIO). 


\section{Introduction}

A large stream of literature has emphasized the importance of academic research for the innovative and competitive performance of firms (Mansfield, 1995 \& 1998; Narin et al, 1997; Cohen et al., 2002; Belderbos et al., 2004; Fleming and Sorenson, 2004; Cassiman et al, 2008). Since the seminal papers of Jaffe (1989) and Nelson (1986) studies have recognized the crucial role of geographical proximity to benefit from spillovers of academic research (Anselin et al., 1997; Bania et al., 1992; Abramovsky et al., 2007; Furman et al., 2006; Autant-Bernard, 2006). Despite this extensive literature analyzing the relationship between industrial $\mathrm{R} \& \mathrm{D}$ and academic research, there is surprisingly little research on whether the promise of spillovers from academia actually affects the locations of international $\mathrm{R} \& \mathrm{D}$ investments by multinational firms. The few existing studies at the regional level ${ }^{1}$ have either taken an aggregate approach examining correlations between foreign R\&D and academic research at the industry level (Cantwell and Piscitello, 2005) or have focused on (foreign) R\&D location choices within one country (Autant-Bernard, 2006; Abramovski et al, 2007; Bania et al, 1992). In reality, however, multinational firms deciding on foreign $\mathrm{R} \& \mathrm{D}$ investments do not limit their attention to regions within one particular country, but they compare regions across multiple countries (Thursby and Thursby, 2008). Hence, there appears to be a discrepancy between the location choice process that is followed by multinational firms and the way prior studies have modeled this process.

This paper differs from prior work by analyzing the impact of academic research strengths of regions on the location choices for foreign $R \& D$ investments by multinational firms within a cross-country perspective. Specifically, we examine whether NUTS-1 regions in Europe with greater academic strength exhibit a greater probability to be selected as the location of greenfield R\&D projects by multinational firms targeting the EU for their R\&D projects. We examine the determinants of the regional location choice for 394 greenfield foreign R\&D projects in NUTS-1 host regions of EU-15 countries during the period 20032008, drawing on cross-border R\&D project information contained in the FDI Markets database published by the Financial Times. We take a broad variety of potential drivers of R\&D location decisions into account, including industry agglomeration, the technological strengths of regions at the industry level (derived from patent information), R\&D tax incentives, wage costs, and measures of the geographic distance and language similarity of

\footnotetext{
${ }^{1}$ Two other studies have been conducted at the country level. Hedge and Hicks (2008) found a positive correlation between US overseas R\&D and the output of countries in S\&E articles. Belderbos et al (2009) found a positive effect of countries' academic research strength on the location choice of first time patent activities.
} 
the home and host regions of investing firms. We measure academic research strength of regions by constructing indicators of the scientific output of universities using annual ISI publication data. We count publications of universities at the regional level and science fields, and take into account the relevant publications for the industry of the investing firm using concordance matrices linking science fields to technologies and industries. Besides examining the overall attractiveness of academic research, we explore whether the supply of $\mathrm{PhD}$ graduates is an important mechanism through which university research benefits firms and impacts on foreign $R \& D$ investments. We employ a mixed logit model to assess the attractiveness of characteristics of host regions on the location decisions of foreign $R \& D$ investments by multinational firms.

The remainder of this paper is organized as follows. In the next section we review the literature on the determinants of the location choice of foreign $R \& D$ investments, focusing on both the regional economics literature and prior studies in the field of international business. Section 3 describes the data and variables employed in the analysis and reports descriptive statistics of the dataset. In section 4 the econometric model is explained after which the empirical results are presented in section 5. Finally, section 6 presents concluding remarks and discusses policy implications and suggestions for further research.

\section{Previous Literature}

Two streams of literature inform about the role of academic research in firms' foreign $R \& D$ location choices at the regional level: the $R \& D$ internationalization literature and the economic geography literature on the role of university-firm interactions.

\section{International R\&D}

The literature on international $R \& D$ distinguishes two main motivations to conduct R\&D abroad (Kuemmerle, 1997). Traditionally, multinational firms invested in R\&D centres abroad to support overseas production and manufacturing facilities and to adopt products and services to the local demand of hosting countries. Sophisticated research activities and the major innovations were still conducted within the research centres of the home country, while foreign $R \& D$ centres were merely focusing on local development and product or process adaptations. This form of foreign $R \& D$ was characterized by an information flow and a transfer of technology assets from the home R\&D centre to the foreign subsidiaries, hence called 'home-base exploiting R\&D'. More recently, multinational firms recognized the 
potential of $R \& D$ capabilities abroad and started foreign $R \& D$ sites to absorb and source foreign technology (Von Zedwitz and Gassmann, 2002; Almeida, 1996; Florida, 1997). Foreign sourced knowledge is transferred to the home $R \& D$ centre of firms to create new products and processes, hence the term 'home-base augmenting R\&D'. Recent studies have confirmed a shift from home-base exploiting to home-base augmenting motives for foreign R\&D investments (Von Zedtwitz and Gassmann, 2002; Todo and Shimizutani, 2008; Cantwell et al., 2004; Cantwell and Janne, 1999) and have investigated to what extent parent firm performance may improve from reverse knowledge transfers from overseas $R \& D$ activities (Penner-Hahn and Shaver, 2005; Song and Shin, 2008; Singh, 2008; Iwasa and Odagiri, 2004). Iwasa and Odagiri (2004) found that R\&D in US affiliates of Japanese firms has a positive impact on parent firms' patent applications in Japan, provided that R\&D activities are focusing on basic research and that they are located in US states with particular technological strengths in the technology field of interest. Song and Shin (2008) and PennerHahn and Shaver (2005) find that effective transfers require a sufficient 'absorptive capacity' at corporate headquarters to utilize foreign know how and R\&D results. Recent work has further shown that reverse knowledge transfers from foreign $R \& D$ can generate spillovers to other firms in the home country (Criscuolo, 2009; Agostino et al., 2012).

An expanding literature has focused (Odagiri and Yasuda, 1996; Patel and Vega, 1999; Kuemmerle, 1999; Kumar, 2001; Chung and Alcacer, 2002; Shimizutani and Todo, 2007; Belderbos et al, 2009) on the determinants of foreign R\&D location decisions of multinational firms. ${ }^{2}$ Prior studies have shown that R\&D is attracted to large markets that have high per capita income levels (Kumar, 2001). R\&D in close proximity to important markets and customers helps companies to stay at the forefront of market developments and to changes in customers' demands (von Zedtwitz and Gassmann, 2002). Further, foreign R\&D location decisions are influenced by the availability of a large pool of qualified scientists and engineers at relatively low costs. Survey reports suggest that foreign R\&D is driven by a lack of sufficient $R \& D$ manpower at low costs in developed home countries (Frost and Sullivan, 2004; Thursby and Thursby, 2006; Lewin et al, 2009). The costs of doing $\mathrm{R} \& \mathrm{D}$ abroad is influenced by wage cost levels of scientists and engineers (Kumar, 2001) and R\&D tax levels (Mudambi and Mudambi, 2005; Buettner and Wamser, 2008), where favorable $R \& D$ tax incentives can compensate for relatively higher wage costs.

\footnotetext{
${ }^{2}$ Remark that most location studies at the regional level (e.g. Basile, 2008; Crozet et al., 2004; Crozet et al., 2004; Disdier and Mayer, 2004; Mataloni, 2007; Arauzo-Carod, 2010) have not focused on foreign R\&D investments, but on the location of foreign manufacturing activities or foreign subsidiaries in general.
} 
Studies have also shown that firms are inclined to locate foreign $R \& D$ activities in clusters of industrial activity (Alcacer and Chung, 2007; Shaver and Flyer, 2001), in particular if these firms are technology laggards in their industries. R\&D activities are undertaken in industry clusters to benefit from agglomeration externalities. Agglomeration externalities are positive externalities that stem from the geographic clustering of firms in an industry, such as the presence of inter-organizational knowledge spillovers, the emergence of specialized pools of labor and suppliers, the visibility of innovation opportunities and peer pressure to innovate (Marshall, 1920; Porter, 1998). Firms are not only attracted to industry clusters, they can also improve their innovative performance once they locate in these clusters (Baptista and Swann, 1998; Beaudry and Breschi, 2003; Baten et al, 2007). Baptista and Swann (1998) found a positive effect of sector employment in the region on the likelihood that manufacturing firms in the United Kingdom innovate. In contrast, Beaudry and Breschi (2003) found no effect of sector employment on firms' innovative performance for a sample of UK and Italian firms: only the concentration of innovative firms (and the size of their accumulated knowledge base) in the sector was found to have a positive impact on firms' technological performance. Baten et al. (2007) came to a similar conclusion. These findings suggest that for firms' innovative performance, the presence of a critical mass in terms of knowledge creation activities in a region, is more important than the overall industrial activity per se (Lecocq and al., 2012).

Location choices for foreign $R \& D$ investments are also influenced by the specific technological strengths and specialization of countries and regions. Patel and Vega (1999) and Le Bas and Sierra (2002) examined patent portfolios of firms and showed that in a majority of technological fields, firms locate foreign R\&D in countries that are specialized in those fields. Related evidence by Chung and Alcacer (2002) suggested that technical capabilities of US states attract foreign manufacturing activities. Technology activities in most fields have the tendency to cluster geographically in a small set of regions (Feldman and Florida, 1994; Audretsch and Feldman, 1996). By undertaking R\&D activities in technology clusters, firms get access to field-specific knowledge and can improve the productivity of their $\mathrm{R} \& \mathrm{D}$ activities.

\section{University-firm interactions: The role of geography}

Universities may impact on firms' innovation activities in different ways. They educate and supply firms with a skilled labor force of scientists and engineers, supply consultants on expert issues, serve as collaboration partners, and transfer new prototypes and 
embryonic technologies to firms (Branstetter and Kwon, 2004; Hall et al, 2003; Cassiman et al, 2008). Last but not least, they perform academic research. Academic research generates (basic) scientific knowledge on which firms can draw in their applied R\&D activities (Klevorick et al, 1995; Mansfield, 1995 \& 1998). Firms that are aware of, and can assimilate, developments in relevant scientific fields may be able to develop a deeper understanding of the technological landscape in which they search for new inventions (Fleming and Sorenson, 2004). This puts firms in a better position to determine which are the right research paths to pursue, and to avoid wasteful experimentation. In addition, scientific knowledge helps firms to better evaluate the outcomes of applied research activities and assess the economic implications. A better understanding of academic research and an effective translation into specific applications can lead to first mover advantages (Rosenberg, 1990; Fabrizio, 2009).

There are different ways through which firms can learn about and benefit from academic research. These mechanisms include joint R\&D projects ${ }^{3}$ (Liebeskind et al, 1996; Link and Scott, 2005), formal IP arrangements, such as licenses and spin-offs (Thursby and Thursby, 2002), training and mobility of scientists and engineers (Salter and Martin, 2001) and informal meetings (Patel and D'Este, 2007). The efficacy of these transfer mechanisms depends on the geographic distance between universities and firms. There are two reasons why this is the case. First, knowledge resulting from basic research is often complex and difficult to codify. Tacit knowledge requires direct interaction to be transferred effectively (Nonaka; von Hippel, 1994), which is facilitated by geographical proximity. Second, the mobility of university graduates -important carriers of (basic) scientific knowledge- is constrained in space (Felsenstein, 1995; Glasson, 2003). A significant number of university graduates look for, and accept, jobs in the region where they received their education. Glasson (2003), for example, calculated that $64 \%$ of the UK-domiciled graduates of Sunderland University are still in the Sunderland region 6 months after graduation.

The geographically bounded nature of university-firm spillovers has been confirmed empirically (Mansfield, 1995; Jaffe et al, 1993; Bellenzon and Schankerman, 2010). Surveying a sample of US firms, Mansfield (1995) showed that geographic proximity determines how frequent universities are consulted by firms on $R \& D$ issues. By comparing the geographic location of citing and cited US patents, Jaffe et al (1993) reveal that patent citations are more likely to come from patents from the same region as the citing patent, compared with a "control frequency" reflecting the concentration of relevant technological

\footnotetext{
${ }^{3}$ Firms have a preference to collaborate with first-tier universities (Laursen et al., 2011; Bishop et al., 2011). This is especially the case for basic scientific research (Mansfield, 1995).
} 
activity in US regions. Using US patent citations to university scientific publications, Belenzon and Shankerman (2010) studied the impact of distance on the diffusion of academic knowledge in the United States. They find that university knowledge spillovers are limited in distance as the patent citation probability sharply declines at distances beyond 100-150 miles.

A large set of studies have analyzed the impact of academic research on the technological performance of nearby located firms. Most of these studies are based on the regional knowledge production framework in which the total technological performance of firms in a region is related to the amount of academic research that is conducted in the region, measured by public R\&D spendings or scientific publications. Jaffe (1989) was the first to estimate the effects of academic research at a regional level. He observed a strong relationship between state-level university $R \& D$ spending and the level of corporate patenting. Follow-up US studies (Acs et al, 1991 \& 1994; Feldman and Florida, 1994; Anselin et al, $1997 \&$ 2000) showed the robustness of the initial findings in different empirical set-ups. More recently, empirical studies have been undertaken for several European countries. Using data for regions in Germany (Blind and Grupp, 1999), France (Autant-Bernard, 2001; Piergiovanni and Santarelli, 2001), Austria (Fischer and Varga, 2003), Italy (Piergiovanni et al., 1997) and Spain (Del Barrio-Castro and Garcia-Quevedo, 2005) for different levels of spatial aggregation, these studies have confirmed the localized effects of academic research on firms' technological performance.

Given the extensive literature analyzing the relationship between academic research and industrial $R \& D$, there is surprisingly litle research on whether the promise of spillovers from academic research actually affects the locations of international $R \& D$ investments by multinational firms. The few existing studies at the regional level have either taken an aggregate approach examining correlations between foreign $R \& D$ and academic research at the industry level (Cantwell and Piscitello, 2005) or focused on R\&D location choices within one country (Bania et al., 1992; Autant-Bernard, 2006; Abramovski et al., 2007). Employing patent data to measure foreign $R \& D$ investments at the industry-level, Cantwell and Piscitello (2005) found that regions with a higher public R\&D employment record more foreign R\&D. Bania et al. (1992) showed that industrial R\&D laboratories in the US were more likely to locate in regions (MSAs) with university research as well as state supported S\&T programs. Similarly, studying regional location decisions for domestic and foreign-owned R\&D performing establishments in France Autant-Bernard (2006) found that firms were more likely to invest in regions with more scientific publications in the related fields of the investing firm. In contrast to the other studies, Audretsch et al. (2004) found no evidence of 
an effect of academic research on the location choices of new firm subsidiaries while studying the geographic distance between universities and new firm establishments in Germany. They did however find evidence of a positive effect of the number of university graduates on firms' location choices.

This paper contributes to the extant literature by combining an analysis of foreign location decisions, drawing on international business perspectives, and an analysis of diversity in regional knowledge bases, relating to the regional economics literature. We focus on the role of academic research strengths (measured in a detailed manner) in foreign $R \& D$ location decisions at the project level and examine the relative explanatory power of academic research compared to industry agglomeration and technological strength. Our paper is the first to examine location decisions for $R \& D$ projects by multinational firms at the regional level while taking a cross-country perspective. Specifically, we examine whether NUTS-1 regions in Europe with greater academic strength exhibit a greater probability to be selected as the location of greenfield $\mathrm{R} \& \mathrm{D}$ projects for multinational firms contemplating locating R\&D projects within the EU.

\section{Data and variables}

To investigate R\&D location choices of multinational firms we used information from the FDI Markets database developed by the Financial Times. This database tracks worldwide cross-border investments during the period 2003-2008 based on information from press releases, investing agencies and - for $90 \%$ of the projects - from investing firms themselves. The database includes information on the parent company of the investing firm (name and location), the destination country and city of the investment, the sector in which the parent company is active and the type investment activity (distinguishing between $R \& D$, manufacturing, distribution, retail, and others). We examine new R\&D investments that are undertaken by manufacturing firms in EU-15 regions for the period 2003-2008. The analysis could not be expanded to all the EU-27 regions as regionalized publication data were not available for East-European countries. Our dataset contains 394 foreign R\&D projects of 286 manufacturing firms within EU-15 countries for the period 2003-2008. Firms based in the US are responsible for the largest share of R\&D projects (45\%), followed by firms in the UK (10\%), Germany (8\%), Japan (6\%) and France (6\%). We distinguish R\&D projects by the industry of the investing firm and distinguish between twelve two-digit NACE manufacturing 
industries. Our analysis includes 65 NUTS-1 regions. ${ }^{4}$ We complemented the dataset on (the location of) of the foreign $R \& D$ investments with information on the characteristics of the NUTS-1 regions and industries, using various data sources.

\section{Dependent variable}

The dependent variable is a binary variable indicating in which NUTS-1 region of the EU-15 countries a multinational firm has invested in a greenfield foreign R\&D project during the period 2003-2008. This variable takes the value one if a particular firm made its $R \& D$ investment in a particular host region $\mathrm{j}$ and zero otherwise. Table 1 shows the distribution of $R \& D$ investments over industries. Most $R \& D$ investments are made by firms in the pharmaceutical and electronics industries with respectively a $34 \%$ and $36 \%$ share in the total number of R\&D investments. The transport and machinery sectors are responsible for about $7 \%$ of the investments, while the remaining industries are less well represented. The lowest numbers of $R \& D$ investments are reported in the textiles, paper, and mineral industries with percentages below one. Table 2 shows the distribution of the projects over NUTS-1 regions. The most attractive NUTS-1 region for foreign R\&D investments in the period 2003-2008 is Ireland (48 projects), closely followed by Catalunya (32 projects). Both regions account for respectively $12 \%$ and $8 \%$ of the total number of greenfield foreign $R \& D$ investments in the period.

Insert Tables 1 and 2 about here

\section{Regional academic research strength}

To assess the role of academic research in attracting foreign $R \& D$ investments, we used information on scientific publications extracted from Thomson Reuters's Web of Science (WoS) to construct appropriate measures. The WoS collects information on scientific articles from peer-reviewed journals. The Web of Knowledge data does not provide the type of organization to which authors are affiliated, which is needed to create an indicator for the scientific research strength of universities. Additionally the WoS database does not

\footnotetext{
${ }^{4}$ NUTS-1 regions in Greece are left out due to lacking information on a number of regional characteristics. In case the investing firm is EU-15 based, the regions in the home country are omitted from the choice set. Since the FDI data only cover cross-border investments, R\&D investments in the home country are not observed.
} 
harmonize names of institutions. Researchers at the Centre of R\&D Monitoring (ECOOM) at the KU Leuven have addressed these shortcomings and allocated all possible spelling variances of institutions to a unique harmonized institution name. This cleaning exercise covers all institutions with at least 20 publications within EU-15 countries (except Greece). For a precise explanation of the name harmonization exercise and statistics concerning the exact coverage of uniquely assigned institutions, we refer to Thijs and Glänzel (2008). To construct an indicator of the academic research strength of regions, we identified the subset of universities on the harmonized list of publishing institutions of ECOOM. Universities are identified by checking for the keywords university, college, school, polytechnic, institute of technology (and their name variants in the EU-15 countries) in the institute names. In addition, we allocated all publishing universities to the NUTS-1 regions where they are located based on institution address. This allows us to calculate the number of university publications per NUTS-1 region at the level of ISI scientific fields. We include publications for which at least one of the authors is affiliated to a university located in the region. Publications are assigned to scientific fields based on the journal (issue) in which they are published. We use an aggregated version of the more than 200 scientific fields developed by Glänzel and Schubert (2003), which distinguishes between 60 scientific fields. We exclude publications from social sciences, arts and humanities in the calculation of industry-level publication counts as academic research in these fields are of minor relevance for industrial $\mathrm{R} \& \mathrm{D}$.

To construct an indicator for the relevant academic publication output per industry in a NUTS-1 region, we used a concordance table developed by Van Looy et al (2004) based on citation frequencies to publications in scientific disciplines as observed on patent documents classified in technology fields. This concordance table assigns to each scientific discipline a probability that it is of relevance to each technology field. Multiplying these probabilities with the available publication counts per science field allowed us to calculate the publication output of universities at the level of technology fields. Finally, we obtained an indicator of the relevant academic strength per industry by using the regional level publication counts for technology fields and a technology-industry concordance table developed by Schmoch et al. (2003) in which technology field are uniquely linked to two-digit NACE industries.

The variable academic research strength is defined as the ratio of the number of publications of university-affiliated authors measured at the industry and regional level, to the 
number of industry establishments in the region ${ }^{5}$. This measure of academic research strength expressed relative to industry size has the advantage that it is less collinear with other sizerelated regional characteristics, which allows for a better identification of the role of academic research. The host regions with the highest ratio of academic publications to industry establishments during 2002-2007 in each industry are presented in table 3. Overall, the highest values for academic research are reported in the electronics, chemicals and pharmaceutical industries. The most frequent observed top regions across industries are Ireland, London, Berlin, Scotland and Hamburg. Ireland is the best performing host region in terms of academic research strength in the chemicals, pharmaceutical and electronics sectors, while London scores best in the food sector, machinery and transport. Hamburg records the highest ranking in the textile and metal sector and the category of other industries (including furniture and recycling). Berlin has the highest rank in the paper, rubber and mineral sectors.

Insert Table 3 about here

\section{Other explanatory variables}

Besides examining the overall attractiveness of academic research for foreign $R \& D$, we explore whether the supply of graduates at the $\mathrm{PhD}$ level is an important mechanism through which academic research benefits firms and impacts on foreign $R \& D$ investment decisions. We create an indicator of the number of graduates with a $\mathrm{PhD}$. We rely on data from the education and training statistics of Eurostat. Preferably we would have used annual data on doctoral graduates for each host region; however, this data is only available at the country level. Hence, we employ the number of doctoral students at the regional level as proxy for the availability of doctoral researchers in a host region. Data on doctoral students is unavailable for NUTS-1 regions in Germany and (partially) for the United Kingdom, which leads to a loss of observations when this variable is included in the empirical models. The number of doctoral students includes all students in the second stage of tertiary education leading to an advanced research qualification, which corresponds to level 6 in the International Standard Classification of Education (ISCED-6). The number of doctoral students covers all fields of disciplines, as the information in Eurostat is not further broken

\footnotetext{
${ }^{5}$ The academic research strength variable is scaled to reduce collinearity and to make it scale insensitive.
} 
down by type of education. The variable doctoral students expresses the number of doctoral students in a region as a ratio of the total number of manufacturing establishments in the region.

Our analysis controls for a wide range of other factors that may influence foreign R\&D location decisions of multinational firms. First, we control for the size of local markets. Most R\&D location studies use variables at the aggregate regional level (population or gross domestic product) to account for market size and market potential. However, market indicators at the industry level are more relevant since multinationals' location decisions are likely to be driven by market conditions relevant for their specific industry. We proxy for the regional market size by including the number of establishments in the industry at the host region level, drawing on the structural business statistics database of Eurostat. In this database an establishment (or 'local unit') is defined as an enterprise or part thereof (e.g. a workshop or factory) that can be identified as situated in a specific location. The variable Industry establishments is the number of establishments in a region and industry. Besides controlling for the local market size, this variable can also be seen as an indicator of the extent of industry agglomeration externalities.

The analysis also controls for the relevant technological strength of regions. We use the number of EPO patents per region and industry as measure of technological strength. To assign patents to regions, we rely on a patent regionalization exercise that is performed at the Centre for R\&D Monitoring (ECOOM) in which the addresses of patent inventors on EPO patents are assigned to corresponding regions (including NUTS-1 regions for EU addresses). If a patent lists multiple inventors based in more than one host region, we assigned the patent to each region. Based on the technology fields (IPC technology classes) of the patents and a concordance table developed by Schmoch et al. (2003) linking IPC classes to industries, we created industry-specific patent counts per host region. We express regional technological strength as the ratio of industry-specific regional patents to the number of establishments in the industry and region to arrive at a measure of the relative technological performance

Other control variables in the model are GDP per capita of host regions is included in the model to capture differences in purchasing power, and the regional unemployment rate. The effect of unemployment on the attractiveness of a region may be ambiguous. A higher unemployment rate may foster the attractiveness of regions to foreign $R \& D$ investments as it indicates a pool of available labor (Chung and Alcacer, 2002). On the other hand, a high unemployment rate may also indicate macroeconomic instability and a weak socio-economic environment, which may make the location less attractive. 
Besides regional characteristics, we also include a number of variables that only vary across host countries, or for which regional data are not available. First, we control for relevant wage costs by including the average gross annual earning of skilled employees at the country level, employing data from UBS (Union Bank of Switzerland) Price \& Earning reports, as regional data on wages for skilled employees are not available. Second, we control for the role of $\mathrm{R} \& \mathrm{D}$ tax incentives. The extent of $R \& D$ tax incentives is measured by the bindex, which is calculated as the present value of before-tax income that a firm needs to generate in order to cover the cost of the initial $R \& D$ investment and to pay the applicable income taxes (Thomson, 2009). In other words, the b-index represents the net cost for the firm to invest in $R \& D$. It takes into account $R \& D$ tax incentives such as tax credits, cost allowances from taxable income, depreciation allowances and the corporate income tax rate (Warda, 2001). When the b-index equals one, the R\&D expenditures are fully deductible as costs, although offering no implicit subsidy to the investing firm. A b-index lower than one indicates that the $\mathrm{R} \& \mathrm{D}$ costs are more than fully deductible, meaning that investing firms benefit from $R \& D$ tax incentives. In the opposite case, when the b-index has a value higher than one, $R \& D$ investments lead to a tax burden. A main advantage of the $b$-index is that it facilitates international comparison of $R \& D$ tax treatments. It is measured at the country level, as in most countries taxation is a federal responsibility and does not vary by region. ${ }^{6}$ In our analysis we include the inverse of the b-index as a measure of the degree of R\&D tax incentives of the host regions. Most European countries report b-indices with values slightly higher than one, indicating a tax burden for R\&D investments. In Austria, France, the Netherlands and the UK the net benefits of investing in R\&D exceed the costs (b-indices approximating values of 0.90 ), indicating effective R\&D tax subsidies. With b-indices of respectively 0.57 and 0.71 , the most attractive $R \& D$ tax treatment systems are observed in Spain and Portugal. Overall, the b-indices remain relatively stable over time, except for Belgium, Denmark and France. The latter countries made remarkable efforts to improve their R\&D tax systems during the period 2002-2007 leading to lower b-indices.

We also include a number of regional characteristics that vary by R\&D investing firm. We include the geographic distance between the home city of the investing parent firm and the host region. A larger distance between the source and destination region may reduce the probability that the region is chosen as a location for R\&D. A larger distance increases the communication and coordination difficulties between parent firms and overseas subsidiaries

\footnotetext{
${ }^{6} \mathrm{~A}$ drawback of the b-index is that it does not take into account R\&D tax subsidies that may differ across regions.
} 
(Ghemawat, 2001), raises transaction costs (Von Zedtwitz and Gassmann, 2002), and reduces the effective transmission of knowledge from foreign R\&D centres to the parent firms (Jaffe et al, 1993; Almeida and Kogut, 1999). Using geographical latitude and longitude information from the Geonames geographical database, we calculated the distance between source cities and host regions with the great-circle distance method. This method provides the shortest distance between any two points on the surface of a sphere, measured along a path on the surface of the sphere. Finally, we include a dummy variable taking the value 1 if the source city and the host region share at least one official language. A shared language can positively affect inward R\&D investments as it facilitates cross-border collaboration and communication between the home and host region (Guellec and Van Pottelsberghe, 2001).

All explanatory variables are one year lagged with respect to the year of the foreign R\&D investment decision. The explanatory variables that are not expressed as ratios or dummies, are log transformed. Summary statistics are displayed in table 4 and a correlation table is included in the appendix.

Insert Table 4 about here

\section{Empirical Model: Mixed logit}

Within the spatial location literature (e.g. Head et al., 1995 \& 1999; Alcacer and Chung, 2007), the conditional logit model (Mc Fadden, 1974) has been widely used to analyze the location determinants of foreign direct investments. A drawback of this model is the restrictive assumption of independence of irrelevant alternatives (IIA). The IIA property states that for any two alternatives the ratio of probabilities is independent of the characteristics of any other alternative in the choice set. This implies that a change in an attribute of one alternative will have the same proportional impact on the probability of each other alternative being chosen. However, this assumption is frequently violated in location choice analyses. To address this problem several studies have implemented 'nested' logit models to partially overcome the restrictive IIA property, by allowing the researcher to partition the choice set into different subsets, called nests (e.g. Crozet et al., 2004; Disdier and Mayer, 2004; Basile et al., 2003). Allowing for correlation in error terms of alternatives 
within a nest, the model relaxes the IIA assumption within nests, while maintaining the hypothesis of no correlation across nests. The main problem of this model, however, is that it is difficult to find appropriate nested structures that adequately capture the correlation between the location alternatives. Failure to find adequate nests results in biased estimations. More recent studies (e.g. Chung and Alcacer, 2002; Basile et al., 2008) have used the mixed logit model. Use of this model fully addresses the problem of violation of the IIA property as the model does not rely on the IIA assumption (McFadden and Train, 2000). In our analysis, we employ the mixed logit model to assess the impact of regions' academic research strength on location decisions for foreign $\mathrm{R} \& \mathrm{D}$ projects.

The mixed logit model starts from a random utility maximization (RUM) setting to assess the location choices of $R \& D$ investments. Having a choice set of alternative host regions $r=1, \ldots, R$ to locate an overseas $R \& D$ project at time $t$, multinational firm $f=1, \ldots, F$ seeks to maximize its expected utility $\left(\mathrm{U}_{\mathrm{frc}, \mathrm{t}}\right)$ as a function of observable regional and country or firm attributes $(\mathrm{X})$ and unobservable factors $\varepsilon_{\mathrm{frc}}$. The expected utility of a multinational firm $f$ choosing region $r$ in host region $c$ among other host regions at time $t$ can be expressed by the functional form:

$$
\mathrm{U}_{\mathrm{frc}, \mathrm{t}}=\alpha V_{\mathrm{c}, \mathrm{t}-1}+\beta V_{\mathrm{r}, \mathrm{t}-1}+\varepsilon \mathrm{frc}=\chi \mathrm{X}_{\mathrm{c}, \mathrm{t}-1}+\delta \mathrm{X}_{\mathrm{ri}, \mathrm{t}-1}+\phi \mathrm{X}_{\mathrm{r}, \mathrm{t}-1}+\gamma \mathrm{X}_{\mathrm{rf}}+\varepsilon \mathrm{frc}
$$

in which $\mathrm{V}_{\mathrm{c}}$ represent a vector of country characteristics and $\mathrm{V}_{\mathrm{r}}$ denote a vector of region characteristics that can vary across industries or firms, while $\varepsilon_{\text {frc }}$ defines a region specific independent random disturbance term. Some variables included in the model are only available at the country level $\left(\mathrm{X}_{\mathrm{c}, \mathrm{t}-1}\right)$ such as $\mathrm{R} \& \mathrm{D}$ tax incentives and wage costs. Other variables differ across regions and industries and are time-variant $\left(\mathrm{X}_{\mathrm{ri}, \mathrm{t}-1}\right)$ such as academic research strength and technological strength. Yet other parameters like GDP per capita are time and region dependent $\left(\mathrm{X}_{\mathrm{r}, \mathrm{t}-1}\right)$, while some factors are firm and region specific but remain constant over time $\left(\mathrm{X}_{\mathrm{r}}\right)$ : language similarity and geographic distance.

While the standard conditional logit model restricts the coefficients $\alpha$ and $\beta$ to be equal across firms, the mixed logit allows the coefficients to be normally distributed with a mean and standard deviation. Accordingly, coefficients are decomposed into a fixed part and a random part that accounts for unobservable effects. The error term incorporates the random components of the coefficients and takes the following form: 


$$
\varepsilon_{\mathrm{frc}}=\kappa_{f} \mathrm{Z}_{c, t-1}+\lambda_{f} \mathrm{Z}_{r, t-1}+\mu_{\mathrm{frc}}
$$

where $Z_{c, t-1}$ and $Z_{r, t-1}$ are vectors of observable variables while $\kappa$ and $\lambda$ are vectors of randomly distributed parameters with zero mean following a normal distribution with variance $\Omega$. The parameter $\mu_{\text {frc }}$ is an independent and identically distributed error term. In a standard conditional logit model, the probability that a given firm $f$ at time $t$ prefers a region $r$ over all other alternatives to locate its R\&D activities could be described as:

$$
P_{\mathrm{cr} \mid \mathrm{f}, \mathrm{t}}=\frac{\exp \left(\alpha V_{c, t-1}+\beta V_{r, t-1}\right)}{\sum_{i=1}^{R} \exp \left(\alpha V_{c, t-1}+\beta V_{r, t-1}\right)}
$$

This probability is conditional on fixed values of $\alpha$ and $\beta$. However, as the coefficients in the mixed logit model are not known but are assumed to follow a certain density function, the probability has to be calculated over all possible values of $\alpha$ and $\beta$. The mixed logit probability can be obtained by taking the integral of the multiplication of the conditional probability (3) with the density functions describing the random nature of the coefficients. There is no closed form solution for the mixed logit probability. Consequently, this probability has to be approximated by simulation techniques. In a first step, values for the coefficients are drawn from their density functions and the conditional probability (equation 3 ) is calculated for these values. This step is repeated several times and the simulated probabilities are averaged to obtain an approximation of the mixed logit probability. We follow the suggestion of Revelt and Train (1998) and use 100 draws for each firm to have confidence in the estimated results. Estimation of the mixed logit model allow us to examine which country or region characteristics are not uniformly important for the location decision of foreign-owned R\&D investments. When the random component of a variable is significant, the characteristic is not valued uniformly among the multinational investors. 


\section{Empirical results}

The results of the mixed logit models are reported in table 5. The table contains three models. Model 1 is a model estimated on the full sample $(n=24249)$. Models 2 and 3 are estimated on a reduced sample, due to the unavailability of doctoral student information for a number of regions. The inclusion of the number of doctoral students as explanatory variable in the baseline model reduces the sample to 15286 observations because of missing data on $\mathrm{PhD}$ graduates for regions in Germany and the $\mathrm{UK}$.

In model 1, the coefficient of our variable of interest, academic research strength, is positive and significant (at the $1 \%$ level). This indicates that multinational firms take the academic research strengths of regions into account in their location decisions for foreign R\&D. In addition, most of the control variables have the expected signs and are significant. Positive and significant effects are found for technological strength, industry establishments, GDP per capita, R\&D tax incentives and language similarity. The unemployment rate and geographic distance variables have the expected negative signs, but are not significant. The only less intuitive result is obtained for $R \& D$ wage costs. The coefficient of this variable is positive and marginally significant (at the $10 \%$ level). A possible explanation for the positive coefficient of wage cost may be that our model controls insufficiently for the availability of qualified human capital in regions and that the wage cost variable partly picks up the positive effect of human capital on the location of R\&D investments, since labor costs in regions with qualified human capital are most likely higher.

Insert Table 5 about here

Models 2 and 3 are included to evaluate the impact of the availability of graduates with a $\mathrm{PhD}$ in a host region on the attraction of foreign $\mathrm{R} \& \mathrm{D}$ investments. To correctly assess the impact of this additional variable, we first re-estimate model 1 on the reduced set of observations, in order to examine if empirical results are robust to this sample attrition. In model 2, the coefficient of academic research strength remains almost unchanged. The magnitude and significance of the coefficients of most control variables do not change 
materially either, with technological strength and GDP per capita as partial exceptions. While the impact of a host region's technological strength increases for the reduced subsample, the effect of GDP per capita decreases. In model 3, the doctoral students variable is included. While the coefficient of number of doctoral students is positive and significant, the coefficient of the academic research strength drops in magnitude but remains positive and significant (at 5\% level). The significant drop in magnitude of the academic research coefficient from model 2 to model 3 indicates that the training and supply of $\mathrm{PhD}$ students is one important mechanism through which academic research attracts foreign R\&D.

Among the random terms of the coefficients, the coefficients on industry establishments, wage costs, language similarity and distance show significant variation. On the other hand, the standard error of the random part of the key variables of interest, academic strength and doctoral students, are not significant, suggesting that the multinational firms in this sample value these region characteristics uniformly in their foreign $R \& D$ location choices.

\section{Robustness tests and alternative specifications}

To assess the robustness of our empirical results, we examined a number of alternative and extended model specifications, which are not reported here due to space limitations. The full results of the robustness checks are available from the authors upon request. First, we examined the potential influence of the characteristics of adjacent regions on foreign $\mathrm{R} \& \mathrm{D}$ location decisions. Our data do not allow us to investigate the influence of all bordering regions, as we do not have information on the characteristics of (bordering) non-EU countries, but we can investigate the role of adjacent regions in the same country. When we added variables measuring average characteristics of adjacent regions in the host country, the results on academic research strength remained roughly the same. The coefficient on GDP per capita in adjacent regions was positive and significant, while the coefficients on industry establishments and technological strength were, perhaps surprisingly, negative and significant; other variables did not have a significant effect. The results on industry establishments and technological strength do not suggest that spillover effects extend across regional borders: rather they seem to suggest that regional clusters in the same country are competing more fiercely for investments. We note, however, that the omission of characteristics of adjacent regions in other countries may introduce a bias in the estimates. Further research should examine the role of adjacent regions and potential spatial correlations in more detail. 
Second, firms may value the importance of region characteristics on foreign $R \& D$ investments differently according to their country of origin. To account for this potential heterogeneity in location decisions we conducted a sensitivity analysis on a subsample of investors that have their corporate headquarters outside the EU-15 countries. From the 394 R\&D projects included in the sample, 263 investments are originating from firms with parent's headquarters located outside the EU-15. Estimations on this subsample were very similar, suggesting no major heterogeneity depending on the source country of investment projects.

Third, we examined to what extent the dispersion of academic research strength within a NUTS-1 region affects the empirical results. In models 1-3 we proxied the probability to benefit from academic research spillovers in a host region by the region's academic research strength and assumed that firms can reap the benefits of academic research in any location within a region. However, this assumption of homogeneity may not hold in large NUTS-1 regions, since preliminary findings of Anselin et al. (1997) and Belenzon and Shankerman (2010) revealed that knowledge spillovers from universities seem to operate at a relatively limited distance (up to 150 miles), while some NUTS-1 regions (e.g. NordreinWestfalen, Bayern, Central Spain, Ireland) exhibit $\backslash$ substantially larger distance dimensions approximating 200-300 miles. Firms concentrated at one end of large NUTS-1 regions may only reap the benefits of academic research conducted in their close vicinity while catching no spillovers from universities at the other extreme of the region. While this heterogeneity will be captured in the random term estimated in the mixed logit models, failure to take into account different degrees of dispersion of academic research may potentially lead to an underestimation of the effect of academic research. To examine a potential negative effect of dispersion of academic research within NUTS-1 regions, we constructed academic publication counts per industry on the NUTS-2 level, following the same procedure as for NUTS-1 regions. We calculated the industry-specific dispersion of academic research in a NUTS-1 region as one minus the sum of the squared shares of each NUTS-2 region in the academic publications in the NUTS-1 region. We then estimated model 1 including the interaction term of the dispersion variable with the variable measuring academic research strength. A negative impact of this interaction term would imply an underestimation of the role of academic research strength in model 1. In that case it would be preferable to conduct analyses on a more fine-grained level such as NUTS-2 or NUTS-3 in order to assess the impact of university spillovers more accurately. Results of this estimation confirmed a negative effect of the interaction, but the coefficient on the interaction term was not 
significantly different from zero, while the magnitude and significance of academic research remained unchanged. We took this as evidence that in general, estimating our model at the NUTS-1 level is unlikely to give biased estimates.

Finally, to investigate whether our results are influenced by residual unobserved country heterogeneity, we estimated a model with a set of country dummies. The coefficient on academic research was somewhat smaller in magnitude (0.36) but remained significant at the $10 \%$ level.

\section{Conclusions}

In this paper we analyzed to what extent academic research in host regions of EU-15 countries attract R\&D investments by multinational firms. We analyzed the determinants of the location of 394 foreign R\&D projects in NUTS-1 regions of EU-15 countries during the period 2003-2008, drawing on the FDI Markets database from the Financial Times. We measured the host region's relevant academic research strength at the industry level using ISI publication counts of authors affiliated to universities located in the host region, and linked scientific fields (of publications) to the industries that they are relevant for. Further, we checked to what extent the supply of $\mathrm{PhD}$ students is an important mechanism through which academic research attracts foreign $R \& D$ investments by multinationals. Our analysis controlled for a broad variety of region-, industry- and firm-specific drivers of R\&D location, including industry agglomeration (the number of establishments), the technological performance of host regions (derived from patent counts in relevant technology fields), $R \& D$ tax incentives, wage costs of skilled employees and variables that measure the geographic distance and language similarity of home and host regions of investing firms. We employed a mixed logit model to assess the influence of regions' academic research strength on the probability that multinational firms locate foreign $R \& D$ investments in a region.

We find that the probability to locate $R \& D$ in a host region is positively affected by the region's academic research strength. In extended specifications in which we accounted for the number of $\mathrm{Ph} . \mathrm{D}$. students in host regions, in addition to the academic research strength variables, we found reduced size and significance of the academic research strength variable, and a significant positive coefficient for the variable measuring the availability of $\mathrm{PhD}$ students. This provides evidence that a major mechanism through which university research attracts foreign $\mathrm{R} \& \mathrm{D}$ is the supply of university graduates at the $\mathrm{PhD}$ level. 
The empirical results indicate that policies to strengthen university research can be effective in attracting $R \& D$ activities of multinational firms and therewith strengthen local R\&D clusters. We emphasize, however, that our findings should not be taken to suggest that publication output itself is creating this attraction to foreign firms' $R \& D$. Rather, the presence of a critical mass of academic research, as indicated by publication output in peer reviewed journals, proxies for opportunities of firms to link up to strong local scientific networks of university researchers, collaborate with university research groups and university spinoffs, or hire capable doctoral researchers from these universities. Future research should aim to disentangle more precisely the essential university characteristics and the precise mechanisms through which industry-science links facilitate industrial R\&D and attract R\&D investments. While our findings are suggestive of the importance of a stable supply of $\mathrm{PhDs}$ graduates by local universities, future research should aim to disentangle more precisely the relative importance of PhD graduates versus other university-firm transfer mechanisms.

Our research is subject to a number of limitations, suggesting a fruitful agenda for future research. A first limitation concerns the quality of our measure of academic research strength of host regions. While we are able to assign publications in scientific fields to the industries for which they are relevant, and calculate sector specific publication counts, we did not control for the quality of publications in our measures. Outstanding quality of research and the presence of 'star scientists' may be an important driver in location decisions for foreign R\&D (see e.g. Laursen et al., 2011; Zucker et al., 1998 \& 2002). Including the number of citations received by university publications could address this limitation. Another limitation of this study concerns the spatial disaggregation of countries into regions. Historically EU's territory was classified by Eurostat in NUTS regions commonly based on the administrative divisions of the Member States. Employing a threshold requirement of a minimum of 3 million and a maximum of 7 million habitants in a NUTS-1 region, this classification is perhaps not the most appropriate division to examine location decisions by multinationals firms in the EU. Future research should therefore experiment with other levels of spatial aggregation, such as mixtures of NUTS-2 regions and NUTS-1 regions. Further disaggregation will have to deal with more limited data availability, however. Finally, it may also be interesting to expand the analyses to domestic R\&D investments, to assess whether the same regional characteristics influence domestic and foreign R\&D investments. 


\section{References}

Abramovsky, L., Harrison, R. Simpson, H. (2007). University Research and the Location of Business R\&D. Economic Journal, 117 (519), pp. 114-141.

Acs Z., Audretsch D. and Feldman M., 1991. Real effects of academic research: Comment. American Economic Review 81, 363-367.

Acs Z., Audretsch D. and Feldman M., 1994. R\&D spillovers and recipient firm size. The

Review of Economics and Statistics 76, 336-340.

Alcacer J. and Chung W. (2007). Location strategies and knowledge spillovers. Management Science, 53(5), 760-776.

Almeida P. (1996), 'Knowledge sourcing by foreign multinationals: patent citation analysis in the US semiconductor industry', Strategic Management Journal, 17, 155-165.

Almeida P. and Kogut B. (1999). Localization of knowledge and mobility of engineers in regional networks. Management Science, 45(71), 905-917.

Anselin L., Varga A. and Adercs Z. (1997). Local geographic spillovers between university research and high technology innovations. Journal of Urban Economics, 42, 422-448.

Anselin L., Varga A. and Acs Z., 2000. Geographic and sectoral characteristics of academic knowledge externalities. Papers in Regional Science 79, 435-445.

Arauzo-Carod J., Liviano-Solis D. and Manjon-Antolin M. (2010). Empirical Studies in Industrial Location: An Assessment of Their Methods and Results, Journal of Regional Science, 50, 3, 685-711.

Audretsch D., Lehmann E. and Warning S. (2004). University Spillovers: Does the Kind of Science Matter? Industry and innovation, 11(3), 193-206.

Audretsch D. and Feldman M. (1996). R\&D spillovers and the geography of innovation and production. The American Economic Review, 86(3), 630-640.

Autant-Bernard C. (2001). Science and knowledge flows: evidence from the French case. Research Policy 30, 1069-1078.

Autant-Bernard C. (2006). Where Do Firms Choose to Locate their R\&D? A Spatial Connditional Logit Analysis on French Data, European Planning Studies, 14, 11871208.

Bania N., Calkins L. and Dalenberg, R. (1992). The effects of regional science and technology policy on the geographic distribution of industrial R\&D laboratories. Journal of Regional Science, 32, 209-228.

Baptista R. and Swann P. (1998). Do firms in clusters innovate more? Research Policy, 27(5), 522-540.

Basile R., Castellani D. and Zanfei A. (2003). Location Choices of Multinational Firms in Europe: The Role of National Boundaries and EU Policy. Centro Studi Luca d'Agliano.

Basile R., Castellani D. and Zanfei A. (2008). Location choices of multinational firms in Europe: The role of EU cohesion policy, Journal of International Economics, 74, 328-340.

Baten L., Spadavecchia A., Streb J. and Yin S. (2007). What made southwest German firms innovative around 1900? Assessing the importance of intra- and inter-industry externalities. Oxford Economic Papers, 59, 105-126.

Beaudry C. and Breschi S. (2003). Are firms in clusters really more innovate? Economics of Innovation and New Technology, 124, 325-342.

Belderbos R., Carree M. and Lokshin B. (2004). R\&D cooperation and firm performance. Research Policy, 33(10), 1477-1492. 
Belderbos, Leten, B., \& Suzuki, S. (2009). Does excellence in academic research attract foreign $R \& D$ ?: UNU-MERIT Working Paper, Maastricht Economic and Social Research and Training Centre on Innovation and Technology.

Belenzon S. and Shankerman M. (2010). Spreading the word: geography policy and university knowledge diffusion. Discussion Paper No. 8002.

Bishop K., D'este P. and Neely A. (2011). Gaining from interactions with universities: Multiple methods for nurturing absorptive capacity. Research Policy, 30-40.

Blind K. and Grupp H., 1999. Interdependencies between the science and technology infrastructure and innovation activities in German regions: empirical findings and policy consequences. Research Policy 28, 451-468.

Branstetter L. Kwon H. (2004). The restructuring of Japanese research and development: The increasing impact of science on Japanese R\&D. RIETI Discussion Paper Series 04-E021.

Buettner, T. and G. Wamser (2008), The Impact of Nonprofit Taxes on Foreign Direct Investment: Evidence from German Multinationals, forthcoming in: International Tax and Public Finance.

Cantwell J. and Janne O. (1999). Technological globalisation and innovative centres: the role of corporate technological leadership and locational hierarchy. Research Policy, 28, 2 3, 119-144.

Cantwell J. and Piscitello L. (2005). Recent location of foreign-owned research and development activities by large multinational corporations in the European regions: The role of spillovers and externalities. Regional Studies, 39, 1-16.

Cantwell J., Dunning J. and Janne O. (2004). Towards a technology-seeking explanation of U.S. direct investment in the United Kingdom. Journal of International Management, $10,1,5-20$.

Cassiman B., Veugelers R. and Zuniga P. (2008). In search of performance effects of (in) direct industry science links. Industrial and Corporate Change vol. 17, no. 4, pp. 611 $-646$.

Chung W. and Alcacer J. (2002). Knowledge Seeking and Location Choice of Foreign Direct Investment in the United States. Management Science, 48(12): 1534- 1554.

Cohen W., Nelson R. and Walsh J. (2002). Links and impacts: The influence of public research on industrial R\&D. Management Science, 48(1), 1-23.

Criscuolo P. (2009). Inter-firm reverse technology transfer: the home country effect of R\&D internationalization. Industrial and Corporate Change, 18, 869-899.

Crozet M., Mayer T. and Mucchielli J-L. (2004). How do Firms Agglomerate? A Study of FDI in France, Regional Science and Urban Economics, 34, 27-54.

D'Agostino L., Laursen K. and Santangelo G. (2012). The impact of R\&D offshoring on the home knowledge production of OECD investing regions. Journal of Economic Geography, forthcoming.

D'Este P. and Patel P. (2007). University-industry linkages in the UK: What are the factors underlying the variety of interactions with industry? Research Policy, 36, 1295-1313.

Del Barrio-Castro T. and Garcia-Quevedo J., 2005. Effects of university research on the geography of innovation. Regional Studies 39(9), 1217-1229.

Disdier A. and Mayer T. (2004). How Different is Eastern Europe? Structure and Determinants of Locational Choices by French Firms in Eastern and Western Europe, Journal of Comparative Economics, 32, 280-296.

Fabrizio K. (2009). Absorptive capacity and the search for innovation. Research Policy, $38(2), 255-267$. 
Feldman M. and Florida R. (1994). The geographic sources of innovation: Technological infrastructure and product innovation in the United States. Annals of the Association of American Geographers, 84(2), 210-229.

Felsenstein D. (1995). Dealing with "induced migration" in university impact studies. Research in Higher Education 36(4), 457-472.

Fleming L. and Sorenson O. (2004). Science as a map in technological search. Strategic Management Journal, 25, 909-928.

Fischer M. and Varga A., 2003. Spatial knowledge spillovers and university research: Evidence from Austria. The Annals of Regional Science 37, 303-322.

Florida R. (1997). The globalization of R\&D: Results of a survey of foreign -affiliated R\&D laboratories in the USA. Research Policy, 26, 85-103.

Frost and Sullivan (2004). Outsourcing Technology in Asia: Analysis of the Changing Face of $R \& D$, San Antonio, TX: Frost and Sullivan Company.

Furman, J., Kyle, M., Cockburn, I. and Henderson, R. (2006). Public \& Private Spillovers, Location and the Productivity of Pharmaceutical Research. NBER Working Papers: 12509.

Ghemawat, P. (2001). Distance still matters. Harvard Business Review, 79(8), 137-147.

Glasson J., 2003. The widening local and regional development impacts of the modern universities - A tale of two cities (and North-South perspectives). Local Economy 18(1), 21-37.

Glänzel W. and Schubert A. (2003). A new classification scheme of science fields and subfields designed for scientometric evaluation purposes. Scientometrics, 56, 3, 357367.

Guellec D. and Van Pottelsberghe B. (2001). The internationalization of technology analyzed with patent data. Research Policy, 30 (8), 1256-1266.

Hall B.H., Link A. and Scott J. (2003) Universities as Research Partners. The Review of Economics and Statistics, 85(2), 485-491.

Head K., Ries D. and Swanson L. (1995). Agglomeration benefits and location choices: Evidence from Japanese manufacturing investments in the United States. Journal of International Economics, 38, 223-247.

Head, C.K., Ries J.C., \& Swenson D.L., 1999. Attracting foreign manufacturing: Investment promotion and agglomeration. Regional Sciences and Urban Economics, 29: 197-218.

Hegde D. and Hicks D. (2008). The maturation of global corporate R\&D: Evidence from the activity of U.S. foreign subsidiaries. Research Policy, 390-406.

Iwasa T. and Odagiri H. (2004). Overseas R\&D, knowledge sourcing, and patenting: An empirical study of Japanese R\&D investment in the US. Research Policy, 33 (5), 807829.

Jaffe A., Trajtenberg M. and Henderson R. (1993). Geographic Localization of Knowledge Spillovers as Evidenced by Patent Citations. The Quarterly Journal of Economics, 108, 3, 577-598.

Jaffe, A., (1989). Real effects of academic research. American Economic Review, 79, 957970.

Kenny M. and Florida R. (1994). The organization and geography of Japanese R\&D: results from a survey of Japanese electronics and biotechnology firms. Research Policy, 23, 305-323.

Klevorick A.K., Levin R., Nelson R. and Winter S., 1995. On the sources and significance of inter-industry differences in technological opportunities. Research Policy 24, 185205.

Kuemmerle W. (1997). Building Effective R\&D Capabilities Abroad. Harvard Business Review, March / April, 61-70. 
Kuemmerle W. (1999). The Drivers of Foreign Direct Investment into Research and Development: An Empirical Investigation. Journal of International Business Studies, 30(1), 1-24.

Kumar, N. (2001). Determinants of location of overseas R\&D activity of multinational enterprises: The case of US and Japanese corporations. Research Policy, 30, 1, pp. 159-174.

Laursen K., Reichstein T. and Salter A. (2011). Exploring the Effect of Geographical Proximity and University Quality on University-Industry Collaboration in the United Kingdom. Regional Studies, 45, 4, 507-523.

Le Bas C. and Sierra C. (2002). Location versus home country advantages in R\&D activities: Some further results on multinationals location strategies. Research Policy, 31, 589609.

Lecocq C., Leten B., Kusters J. and Van Looy B. (2012). Do firms benefit from being present in multiple technology clusters? An assessment of the technological performance of biopharmaceutical firms. Regional Studies, forthcoming.

Lewin A., Massini S. and Peeters C. (2009). Why are companies offshoring innovation? The emerging global race for talent. Journal of International Business Studies, 40, 901925.

Liebeskind J., Oliver A., Zucker L. and Brewer M. (1996). Social networks, learning and flexibility: Sourcing scientific knowledge in new biotechnology firms. Organization Science 7(4), 428-442.

Link A. and Siegel D., 2005. University-based technology initiatives: Quantitative and qualitative evidence. Research Policy 34(3), 253-257.

Mansfield E. (1995). Academic research underlying industrial innovations: Sources, characteristics and financing. The Review of Economics and Statistics, 77, 55-65.

Mansfield E. (1998). Academic research and industrial innovation: An update of empirical findings. Research Policy 26, 773-776.

Marshall A. (1920). Principles of Economics, London, MacMillan.

Mataloni R., 2007. Do U.S. Multinationals Engage In Sequential Choice? Evidence from New Manufacturing Operations in Europe. Prepared for the OECD Committee on Industry, Innovation and Entrepreneurship, Working Party on Globalisation of Industry, Paris, France, November 14-15

McFadden D. (1974). Conditional logit analysis of qualitative choice behavior In: Zarembka P., Frontiers in Econometrics. Academic Press, New York, 105-142.

McFadden, D., \& Train, K. (2000). Mixed MNL models for discrete response. Journal of Applied Econometrics, 15(5), 447-470.

Mudambi, R., \& Mudambi, S. M. (2005). Multinational enterprise knowledge flows: The effect of government inward investment policy. MIR: Management International Review, 45(2), 155-178.

Narin F. and Noma E., 1987. Patents as indicators of corporate technological strenght. Research Policy 16 (2-4), 143-155.

Nelson R. (1986). Institutions supporting technical advance in industry. American economic review, 76, 186-189.

Nonaka I. (1994). A dynamic theory of organizational knowledge creation. Organization Science 5(1), 14-37.

Odagiri H. and Yasuda H. (1996). The Determinants of Overseas R\&D by Japanese Firms: An Empirical Study at the Industry and Company Levels. Research Policy, 25, 10591079.

Patel P. and Vega M. (1999). Patterns of internationalization of corporate technology: Location vs. home country advantages. Research Policy, 28, 145-155. 
Penner-Hahn J. and Shaver M. (2005). Does international research and development increase patent output? An analysis of Japanese pharmaceutical firms. Strategic Management Journal, 26, 121-140.

Piergovanni R., Santarelli E. and Vivarelli M., 1997. From which source do small firms derive their innovative inputs? Some evidence from Italian industry. Review of Industrial Organization 12, 243-258.

Piergiovanni R. and Santarelli E., 2001. Patents and the geographic localization of R\&D spillovers in French manufacturing. Regional Studies 35(8), 697-702.

Porter M. (1998). Clusters and the new economics of competition. Harvard Business Review, November-December, 77-90.

Revelt and Train (1998). Mixed Logit with Repeated Choices: Households' Choice of Appliance Efficiency Level. Review of Economics and Statistic 53(4), 647-657.

Rosenberg N. (1990). Why do firms do basic research (with their own money)? Research Policy, 19(2), 165-174.

Salter A. and Martin B. (2001), The Economic Benefits of Publicly Funded Basic Research: A Critical Review, Research Policy, 30, 509-32.

Schmoch, U., Laville, F., Patel, P., \& Frietsch, R. (2003). Linking technology areas to industrial sectors. Final Report to the European Commission, DG Research.

Shaver J. and Flyer F. (2000). Agglomeration economies, firm heterogeneity, and foreign direct investment in the United States. Strategic Management Journal, 21(12), 11751193.

Shimizutani S. and Todo, Y. (2007). What determines overseas R\&D activities? The case of Japanese multinational firms. Research Policy, 37, 530-544

Singh, J. (2008). Distributed R\&D, cross-regional knowledge integration and quality of innovative output. Research Policy, 37, 77-96.

Song, J. and Shin, J. (2008). The paradox of technological capabilities: a study of knowledge sourcing from host countries of overseas R\&D operations. Journal of International Business Studies, 39, 291-303.

Thijs B. and Glänzel W. (2008). A structural analysis of publication profiles for the classification of European research institutes. Scientometrics, 74, 2, 223-236.

Thomson, R. (2009). Tax policy and the globalisation of R\&D. Working papers in Trade and Development. The Australian National University working paper, 3, 1-74.

Thursby J. and Thursby M.C., 2002. Who is selling the ivory tower? Sources of growth in university licensing. Management Science 48, 90-140.

Thursby J. and Thursby M. (2006). Here or There? A Survey of Factors in Multinational $\mathrm{R} \& \mathrm{D}$ Location. Report to the Government-University-Industry Research Roundtable, National Academy of Sciences.

Todo Y. and Shimizutani S. (2008). Overseas R\&D Activities and home productivity growth. Journal of Industrial Economics, 56(4), 752-777.

Van Looy, B., Tijssen, R.J.W. Callaert J, Van Leeuwen T. \& Debackere K. (2004). European science in industrial relevant research areas: Development of an indicator-based bibliometric methodology for performance analyses of countries and research organizations, Report for the European Commission (DG Research) produced by CWTS (Leiden) and INCENTIM (Leuven).

Von Zedtwitz M. and Gassmann O. (2002). Market versus Technology Drive in R\&D Internationalization: Four Different Patterns of Managing Research and Development. Research Policy, 31(4), 569-588.

Von Hippel E., 1994. Sticky information and the locus of problem solving: Implications for innovations. Management Science 40(3), 429-439. 
Warda J. (2001). Measuring the value of R\&D tax treatment in OECD countries. STI Review special issue on new science and technology indicators, 27, pp 185-211.

Zucker L., Darby M. and Armstrong J. (2002). Commercializing knowledge: University science, knowledge capture, and firm performance in biotechnology. Management Science, 48(1), 2002.

Zucker L., Darby M., and Brewer M. (1998). Intellectual Human Capital and the Birth of U.S. Biotechnology Enterprises. American Economic Review, 88 (1), 290-306. 
Table 1: Cross-border R\&D investments by industry, 2003-2008

\begin{tabular}{l|rr} 
Industry & Frequency & Percentage \\
\hline Food & 15 & 3.81 \\
Textiles & 1 & 0.25 \\
Paper & 2 & 0.51 \\
Chemicals & 20 & 5.08 \\
Pharmaceuticals & 134 & 34.01 \\
Rubber & 8 & 2.03 \\
Minerals & 1 & 0.25 \\
Metals & 8 & 2.03 \\
Machinery & 27 & 6.85 \\
Electronics & 143 & 36.29 \\
Transport & 26 & 6.60 \\
Others & 9 & 2.28 \\
\hline Total & $\mathbf{3 9 4}$ & $\mathbf{1 0 0}$
\end{tabular}

Table 2: Distribution of cross border R\&D investments over NUTS-1 regions, 2003-2008

NUTS-1 region

Ireland (IE0)

Catalunya (ES5)

East of England (UKH)

Scotland (UKM)

Méditeranée (FR8)

Northern Ireland (UKN)

Denmark (DK0)

South East England (UKJ)

Flanders (BE2)

Île de France (FR1)

North West Italy (ITC)

Bassin Parisien (FR2)

East Sweden (SE1)

Bayern (DE2)

Comunidad de Madrid (ES3)

West France (FR5)

Central France (FR7)

East France (FR4)

Nordrhein-Westfalen (DEA)

Finland (FI1)

Central Italy (ITE)

Portugal (PT1)

West Austria (AT3)

Baden-Württemberg (DE1)

South Spain (ES6)

South West France (FR6)

Wales (UKL)

East Austria (AT1)

South Austria (AT2)

Walloon Region (BE3)

West Netherlands (NL3)

South Netherlands (NL4)

South Sweden (SE2)
Frequency Percentage

48

32

$16 \quad 4.06$

$16 \quad 4.06$

$15 \quad 3.81$

$15 \quad 3.81$

$13 \quad 3.3$

13

12

12

12

11

11

11
10

10

10

9
7

6

6

6

6

5

5

5

5

5

4

4

4

4

4

4
NUTS-1 region

North East England (UKC)

London (UKI)

Berlin (DE3)

Hamburg (DE6)

Sachsen (DED)

North West Spain (ES1)

Nord-Pas-de-Calais (FR3)

West Midlands (UKG)

South West England (UKK)

Hessen (DE7)

North East Spain (ES2)

Central Spain (ES4)

Isole (ITG)

Brussels (BE1)

Niedersachsen (DE9)

Rheinland-Pfalz (DEB)

North East Italy (ITD)

Southern Italy (ITF)

Luxembourg (LU0)

Northern Netherlands (NL1)

Eastern Netherlands (NL2)

North Sweden (SE3)

North West England (UKD)

Yorkshire and the Humber (UKE)

East Midlands (UKF)

Brandenburg (DE4)

Bremen (DE5)

Mecklenburg-Vorpommern (DE8)

Frequency Percentage

Saarland (DEC)

Sachsen-Anhalt (DEE)

Schleswig-Holstein (DEF)

Thüringen (DEG)

Total

$\begin{array}{rr}\text { Frequency } & \text { Percentage } \\ 4 & 1.02\end{array}$

1.02

0.76

0.76

0.76

0.76

0.76

0.76

0.76

0.51

0.51

0.51

0.51

0.25

0.25

0.25

0.25

0.25

0.25

0.25

0.25

0.25

0.25

0.25

0.25

0.00

0.00

0.00

0.00

0.00

0.00 0.00 
Table 13: Host regions with the highest levels of academic research strength per industry

\begin{tabular}{|l|r|l|r|l|l|l|r|}
\hline NUTS-1 region & \multicolumn{1}{|l|}{ Food } & NUTS-1 region & Textile & NUTS-1 region & Paper & NUTS-1 region & Chemicals \\
\hline London (UKI) & 387.46 & Hamburg (DE6) & 98.66 & Berlin (DE3) & 18.51 & Ireland (IE0) & 13319.35 \\
\hline South East England (UKJ) & 219.54 & Berlin (DE3) & 49.16 & Ireland (IE0) & 15.35 & Mecklenburg (DE8) & 7140.08 \\
\hline Scotland (UKM) & 162.67 & Sachsen-Anhalt (DEE) & 28.18 & Scotland (UKM) & 12.51 & Berlin (DE3) & 6307.07 \\
\hline East Sweden (SE1) & 162.06 & Mecklenburg (DE8) & 25.87 & Saarland (DEC) & 12.46 & London (UKI) & 5147.42 \\
\hline Ireland (IE0) & 159.20 & Ireland (IE0) & 21.49 & Hamburg (DE6) & 10.77 & Scotland (UKM) & 4562.68 \\
\hline
\end{tabular}

\begin{tabular}{|l|r|l|r|l|r|l|r|}
\hline NUTS-1 region & \multicolumn{1}{|l|}{ Pharma } & NUTS-1 region & Rubber & NUTS-1 region & Minerals & NUTS-1 region & Metals \\
\hline Ireland (IE0) & 36290.21 & Berlin (DE3) & 154.98 & Berlin (DE3) & 614.38 & Hamburg (DE6) & 168.26 \\
\hline Mecklenburg (DE8) & 19791.84 & Hamburg (DE6) & 131.03 & London (UKI) & 549.15 & London (UKI) & 135.11 \\
\hline Berlin (DE3) & 18244.94 & London (UKI) & 125.11 & Hamburg (DE6) & 487.42 & Berlin (DE3) & 123.85 \\
\hline London (UKI) & 17827.51 & West Netherlands (NL3) & 105.41 & Scotland (UKM) & 317.20 & Ireland (IE0) & 110.70 \\
\hline West Netherlands (NL3) & 14850.81 & Scotland (UKM) & 85.27 & South East England (UKJ) & 250.89 & Scotland (UKM) & 90.10 \\
\hline
\end{tabular}

\begin{tabular}{|l|r|l|r|l|r|l|l|}
\hline NUTS-1 region & Machinery & NUTS-1 region & lectronics & NUTS-1 region & Transport & NUTS-1 region & Others \\
\hline London (UKI) & 1670.79 & Ireland (IE0) & 5097.67 & London (UKI) & 563.19 & Hamburg (DE6) & 32.95 \\
\hline Ireland (IE0) & 1146.25 & Scotland (UKM) & 4851.17 & Berlin (DE3) & 535.60 & Berlin (DE3) & 31.62 \\
\hline Scotland (UKM) & 942.85 & London (UKI) & 4711.18 & Ireland (IE0) & 353.78 & Scotland (UKM) & 27.22 \\
\hline Berlin (DE3) & 871.60 & West Netherlands (NL3) & 3383.73 & Hamburg (DE6) & 340.71 & London (UKI) & 24.33 \\
\hline Walloon Region (BE3) & 771.77 & North East England (UKC) & 3287.02 & Scotland (UKM) & 279.47 & Ireland (IE0) & 19.58 \\
\hline
\end{tabular}

Note: numbers represent the academic research strength variable multiplied by 1000 . 


\section{Table 4: Definition and summary statistics of explanatory variables}

\begin{tabular}{|c|c|c|c|}
\hline Name & Definition & Mean & Stdev. \\
\hline Academic research strength & $\begin{array}{l}\text { Ratio of university publications to industry establishments in NUTS-1 region, at the } \\
\text { industry level }\end{array}$ & 2,774 & 4,194 \\
\hline Technological strength & Ratio of patents to industry establishments in NUTS-1 region, at the industry level & 0,788 & 1,177 \\
\hline Doctoral students & $\begin{array}{l}\text { Ratio of doctoral students in NUTS-1 region to all industry establishments in NUTS-1 } \\
\text { region }\end{array}$ & 0,297 & 0,214 \\
\hline Industry establishments & $\begin{array}{l}\text { Logarithm of the number of industry establishments in NUTS-1 region, at the industry } \\
\text { level }\end{array}$ & 6,634 & 1,274 \\
\hline GDP per capita & Logarithm of GDP per capita of NUTS-1 region & 3,284 & 0,297 \\
\hline Unemployment rate & Logarithm of unemployment rate of NUTS-1 region (percentage) & 1,989 & 0,495 \\
\hline Geographic distance & $\begin{array}{l}\text { Logarithm of geographical distance between the source city of the investing firm and the } \\
\text { NUTS-1 region }\end{array}$ & 8,133 & 1,128 \\
\hline Language similarity & $\begin{array}{l}\text { Dummy variable indicating the language similarity between the source city of the } \\
\text { investing firm and the NUTS- } 1 \text { regions }\end{array}$ & 0,159 & 0,366 \\
\hline Wage cost & Logarithm of wage costs of skilled employees of the host country & 10,325 & 0,316 \\
\hline R\&D tax incentives & Logarithm of (1 / b-index) & 4,703 & 0,168 \\
\hline
\end{tabular}


Table 5: Mixed logit analysis of European regional location choices for R\&D investment projects, 2003-2008

\begin{tabular}{|c|c|c|c|}
\hline & Model 1 & Model 2 & Model 3 \\
\hline Academic research strength & $\begin{array}{l}0.061 * * * \\
(0.012)\end{array}$ & $\begin{array}{l}0.059 * * * \\
(0.013)\end{array}$ & $\begin{array}{l}0.036 * * \\
(0.015)\end{array}$ \\
\hline Technological strength & $\begin{array}{l}0.173 * * * \\
(0.041)\end{array}$ & $\begin{array}{l}0.310 * * * \\
(0.066)\end{array}$ & $\begin{array}{l}0.300 * * * \\
(0.074)\end{array}$ \\
\hline Doctoral students & & & $\begin{array}{l}1.567 * * * \\
(0.299)\end{array}$ \\
\hline Industry establishments & $\begin{array}{l}0.515^{* * *} \\
(0.087)\end{array}$ & $\begin{array}{l}0.506^{* * * *} \\
(0.093)\end{array}$ & $\begin{array}{l}0.624 * * * \\
(0.100)\end{array}$ \\
\hline GDP per capita & $\begin{array}{l}0.735^{* * * *} \\
(0.206)\end{array}$ & $\begin{array}{l}0.490 * * \\
(0.223)\end{array}$ & $\begin{array}{l}-0.138 \\
(0.260)\end{array}$ \\
\hline Unemployment rate & $\begin{array}{l}-0.166 \\
(0.122)\end{array}$ & $\begin{array}{l}0.144 \\
(0.135)\end{array}$ & $\begin{array}{l}0.022 \\
(0.146)\end{array}$ \\
\hline Geographic distance & $\begin{array}{l}-0.077 \\
(0.249)\end{array}$ & $\begin{array}{l}-0.058 \\
(0.248)\end{array}$ & $\begin{array}{l}-0.238 \\
(0.240)\end{array}$ \\
\hline Language similarity & $\begin{array}{l}1.014 * * * \\
(0.163)\end{array}$ & $\begin{array}{l}0.963 * * * \\
(0.299)\end{array}$ & $\begin{array}{l}0.886^{* * * *} \\
(0.310)\end{array}$ \\
\hline \multicolumn{4}{|l|}{ Host country variables } \\
\hline Wage costs & $\begin{array}{l}0.644^{*} \\
(0.383)\end{array}$ & $\begin{array}{l}0.350 \\
(0.369)\end{array}$ & $\begin{array}{l}0.629 \\
(0.420)\end{array}$ \\
\hline R\&D tax incentives & $\begin{array}{l}2.611 * * * \\
(0.384)\end{array}$ & $\begin{array}{l}1.936 * * * \\
(0.414)\end{array}$ & $\begin{array}{l}1.682^{* * * *} \\
(0.438)\end{array}$ \\
\hline \multicolumn{4}{|l|}{ Random parts coefficients } \\
\hline $\begin{array}{l}\text { Industry establishments } \\
\text { Language similarity }\end{array}$ & $0.493 * * *$ & $\begin{array}{l}0.405 * * \\
2.049 * *\end{array}$ & $0.541 * * *$ \\
\hline Geographic distance & $1.283 * * *$ & $1.017 * * *$ & $0.767 *$ \\
\hline Wage cost & $2.089 * * *$ & $1.282 * *$ & $-1.690 * * *$ \\
\hline No. of observations & 24249 & 15286 & 15286 \\
\hline Wald chi square & $181.1 * * *$ & $93.86 * * *$ & $124.8 * * *$ \\
\hline
\end{tabular}

Notes: Error terms are clustered by investing firm. Significance levels: *** $\mathrm{p}<0.01$; ** $\mathrm{p}<0.05$; $\mathrm{p}<<0.10$. Only significant random components of the coefficients are reported. 


\section{APPENDIX: Correlation table}

\begin{tabular}{|c|c|c|c|c|c|c|c|c|c|c|c|}
\hline & 1 & 2 & 3 & 4 & 5 & 6 & 7 & 8 & 9 & 10 & 11 \\
\hline 1 Foreign $R \& D$ investment & 1.000 & & & & & & & & & & \\
\hline 2 Academic research strength & 0.045 & 1.000 & & & & & & & & & \\
\hline 3 Technological strength & 0.018 & 0.468 & 1.000 & & & & & & & & \\
\hline 4 Doctoral students & 0.069 & 0.300 & 0.184 & 1.000 & & & & & & & \\
\hline 5 Industry establishments & 0.024 & -0.449 & -0.313 & -0.209 & 1.000 & & & & & & \\
\hline 6 GDP per capita & 0.026 & 0.125 & 0.190 & 0.253 & -0.166 & 1.000 & & & & & \\
\hline 7 Unemployment rate & -0.039 & -0.050 & 0.006 & 0.031 & -0.113 & -0.404 & 1.000 & & & & \\
\hline 8 Geographic distance & -0.014 & -0.011 & -0.030 & 0.027 & 0.052 & -0.059 & 0.044 & 1.000 & & & \\
\hline 9 Language similarity & 0.051 & 0.145 & 0.010 & 0.158 & -0.101 & 0.115 & -0.229 & -0.058 & 1.000 & & \\
\hline 10 Wage cost & 0.000 & 0.261 & 0.226 & 0.236 & -0.352 & 0.476 & -0.233 & -0.040 & 0.202 & 1.000 & \\
\hline $11 \mathrm{R} \& \mathrm{D}$ tax incentives & 0.029 & -0.098 & -0.238 & 0.104 & 0.119 & -0.301 & -0.012 & 0.030 & -0.042 & -0.413 & 1.000 \\
\hline
\end{tabular}

Notes: All correlations are presented for the baseline model $(\mathrm{n}=24249)$, except for the correlations with doctoral students that are only available for the reduced sample $(n=15286$; in grey) 